\title{
Svineinfluensa for 70 år siden
}

«Den senere tids forskning i alle land har bekreftet at den epidemiske influensa skyldes et virus», het det i en nyhetsartikkel i Tidsskriftet i 1939 (s. 818). Samme år holdt reservelege Frithjof Wigers (1908-57) et foredrag om influensa i Det medicinske selskab i Bergen. Foredraget ble senere trykt i Tidsskriftet (1939; 59: 1247-53). I artikkelen bruker Wigers betegnelsen svineinfluensa, på engelsk kalt «hog flu». Wigers arbeidet på denne tiden ved epidemiavdelingen Haukeland sykehus og hadde våren 1939 vært på et studieopphold i London for å «se litt av det eksperimentelle influensaarbeide». | 1941 åpnet han privatpraksis i Bergen som spesialist i barnesykdommer.

\section{En oversikt over de nyere forskningsresultater vedrørende influensa}

Efter at Pfeiffer ${ }^{1}$ i 1891 under et nytt utbrudd av den influensapandemi som raste mellem 1889 og 1892, fant den lille gramnegative stav som er opkalt efter ham, mente man lenge å ha funnet influensaens årsak. Det har dog alltid vært de som har tvilt på denne bacilles etiologiske betydning, og efter hvert blev det klart at den ikke fylte de fordringer som er opstillet av Henle og Koch. Man fant den slett ikke i alle tilfelle av typisk influensa, og på den annen side fant man den ved en rekke infeksiøse processer som ikke hadde noget med influensa å gjøre. Videre lyktes det ikke på forsøksdyr å fremkalle noget som lignet influensa hos mennesket. [...]

Slik var stillingen inntil det store fremskritt blev gjort via veterinærmedisinen. I 1918 blev der blandt den store svinebestand i Nord-Amerika iakttatt en meget smittsom sykdom, som klinisk ytret sig ved feber, appetittløshet, apati, hoste og åndedrettsbesvær. Ved seksjon fantes bronkitt, peribronkitt og katarralsk bronkopneumoni. Denne epidemi gjentok sig i årene 1928 og 1929 og blev på grunn av den kliniske og epidemiologiske likhet med menneskelig influensa av dyrlægene kalt hog-flu. [...] Også Shope ${ }^{2}$ betonet sterkt likheten mellem denne hog-flu og influensa hos mennesket, og virusforskerne ventet nu bare på en ny influensaepidemi for å kunne studere sykdommen ut fra denne nye synsvinkel.

De heldige var forskerne ved National Institute for Medical Research i London: Laidlaw, Andrewes og Wilson-Smith, idet der kom en influensaepidemi i England i 1933. [...] At sykdommen kan føres tilbake til mennesket blev i 1936 vist ved et uheld, idet en ferret nøs rett i ansiktet på en av lægene. Denne fikk kort efter typisk influensa og man kunde fra hans nasofarynks isolere virus, identisk med det som fantes hos den ilder som hadde infisert ham.

\footnotetext{
${ }^{1}$ Richard Friedrich Johannes Pfeiffer (1858-1945), tysk lege og bakteriolog. Pfeiffers basill kalles nå for Haemophilus influenzae

${ }^{2}$ Richard Edwin Shope (1901-66), amerikansk virolog
} 